\title{
Geomorphological Evaluation of Using the Digital Elevation Model (DEM) for Identifying the Morphmetrical Characteristics of Basins Case study: Wadi Abu Had, Eastern desert, Egypt
}

\author{
Dr. Ahmed Mohamed Ahmed Abou Raiah*
}

\begin{abstract}
The analysis of morphmetric drainage network could be derived from varity of sources including (Topographic maps - Aerial photographs - Field study - Satellite Images), but recently from DEM. Manual drawing of drainage network is a very contradicted process very even within the same drainage network, which is reflected on the forms of drainage basins.

A cartographic representation of drainage networks involved the use of topographic maps and aerial photographs to the satellite image, but now DEM is used, due to the increase of the resolution of DEM and the increase of the capacity of the computer and the use of geographic information systems (GIS), which make the derivation process faster and more objective than traditional manual techniques applied to topographic maps and other sources.
\end{abstract}

* Department of Geography, Faculty of Arts, Fayoum University; Egypt.

$-1-$ 
The researcher will be extracting drainage networks from Digital Elevation Model and the various sources of Wadi Abu Had catchment's, Eastern desert of Egypt, allowing comparison of drainage networks extracted from different sources to reach a high degree of spatial and morphometrical coincidence.

This is employing the quality of the DEM used in the hydrological analysis and the insensitivity of the automatic extraction process to the source or resolution high quality DEM.

The research aims to: Measure morphmetric and morphological characteristics of networks and drainage basins of different sources, and compare the results with the results of DEM to access the accuracy of DEM results.

Key Words: Geomorphological evaluation, DEM, Drainage network, morphometric analysis

\section{Introduction}

Several studies in geomorphology, hydrology, and related disciplines require the delineation of drainage networks and basins. Manual interpretation of streams and dividing the basins and networks from topographic maps, aerial photographs, digitization of geometric or topologic properties is pretty boring especially for small scale drainage networks. Also If the networks have been recorded by other methods (e.g., remotely sensed image), this adds additional effort. Measuring the height of the earth's surface reached high levels of accuracy and description, digital elevation model (DEM) offers numerous topographical data, which can be used in various studies of the earth sciences, it is easy to apply these techniques to a variety of geomorphological, hydrological and cartographic researches.

Cartographic representation of topography has been gradually replaced by digital representation using DEMs (Tarboton and Ames, 2001). This is due to the increasing availability of DEMs and increase in computing power, which make the derivation process faster and more objective than traditional manual techniques applied to topographic maps (Tribe, 1991) in principle, the extracted drainage networks can be validated by comparing them with standard drainage networks in the same region. 


\section{Study Aarea}

The study area watershed of Wadi Abu Had is located at western part of The Red Sea, Egypt, and extends between latitudes $27^{\circ} 34^{`} 23$ ", $27^{\circ} 47^{\prime} 23^{\prime \prime}$ North, and between longitudes $33^{\circ} 01^{\prime} 25^{\prime \prime}, 33^{\circ} 30^{\prime} 01$ " East, to the north of Hurghada City (Fig. 1). The area has moderate to high relief, dissected to intensive drainage networks, and the basin area is approximately $320 \mathrm{~km}^{2}$. It experiences an arid zone with the majority of from high intensity, short duration rain falling in autumn and spring, which is flash flooding in the study area.

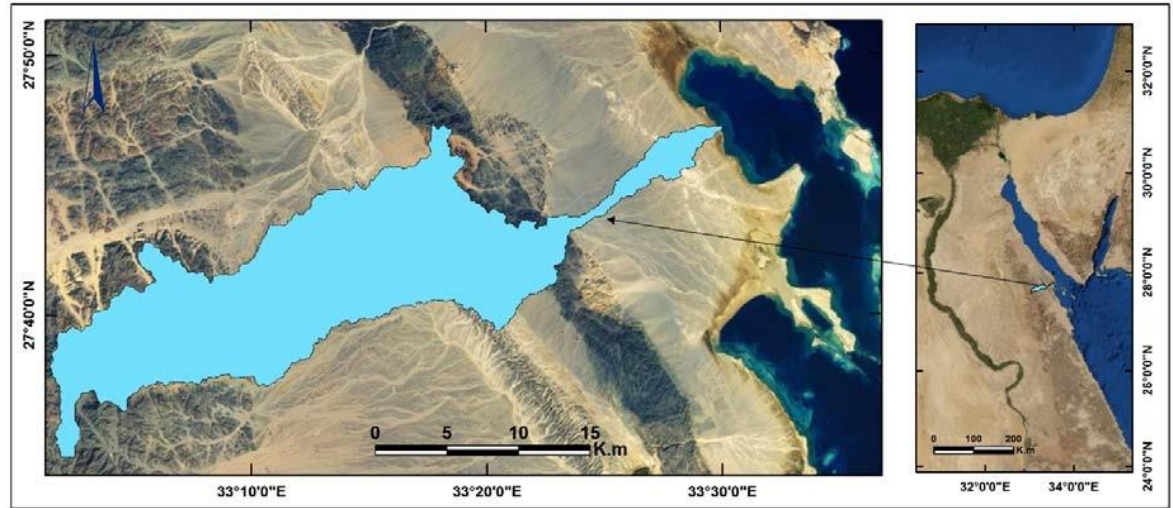

Figure 1. Location of the study area.

\section{Geological Properties}

The Surface geological of the basin Wadi Abu Had, can be summarized as following properties (Geo., Survey, Egypt, 2005) (Fig. 2):

\section{The pre -Cambrian rocks}

The pre -Cambrian rocks constitute the upstream area of the basin, and constitute about $27.8 \%$ of the total area of the basin. These rocks are characterized by their drainage network clearly and easily identified even by traditional methods. The rocks consist of the following;

- Acidic to intermediate Metavolcanics and related volcaniclastics: Metadacite and metarhoylite with lapilli ash and agglomerate tuff. 
- Gabbro-Diorite: Mesocratic to melanocratic, hornblende pyroxene gabbro and hornblende biotite diorite.

- Granodiorite-Tonalite: Medium to coarse grained, equigranular biotite and hornblende.

- Dukhan Volcanics: Quartz porphyry (Rhyolite to Rhyodacite).

- Hammamat group: Conglomerate, greywake with alternating, feldspathic siltstone.

- Monzogranite: Biotite, muscovite monzogranite.

- Alkali feldspar granite: medium to coarse grained, perthite, biotite to riebeckite and quartz.

\section{The sedimentary rocks:}

Sedimentary rocks cover most of the basin, where approximately $72.2 \%$ of the total area, and it is difficult in these sediments to select drainage network by traditional methods, under the conditions of the current dryness and the erosion wind activities, The accuracy of drainage network depends on the experience of personal, as opposed to the modern methods that depend on elevation differences to determine the drainage network. These rocks consist of the following;

\section{Late Cretaceous}

* Sudr Formation: White to pale grey chalk and chalky limestone.

* Duwwi Formation: Dark-grey clay with inter bedded thin phosphatic and sandstone layers.

* Quseir Formation: Variegated shale with minor sandstone and limestone beds.

* Taref Formation: Red to brown, medium to coarse grained, ferruginous, cross-bedded sandstone with pebble beds.

* Wata Formation: Yellowish brown limestone, partly siliceous and dolomitic, marl inter beds, and intercalations of sand and shale.

- Paleogene

* Thebes Formation: Pale white, porcellaneous chalky limestone with brown to black flint bands and nodules.

* Esna Formation: Yellowish pale brown to green clay and shale rich in foraminifera. 


\section{- Quaternary}

* Recent wadi deposits: detritals of sands, silts and gravels * Sabkhah deposits: fine sands, silts, silty clays and evaporites.

* Alluvial wadi deposits: silts, sands and conglomerates.

* Gabir Formation: yellow to brown calcareous sandstone, limestone, grit and gravels with oyster fossils.

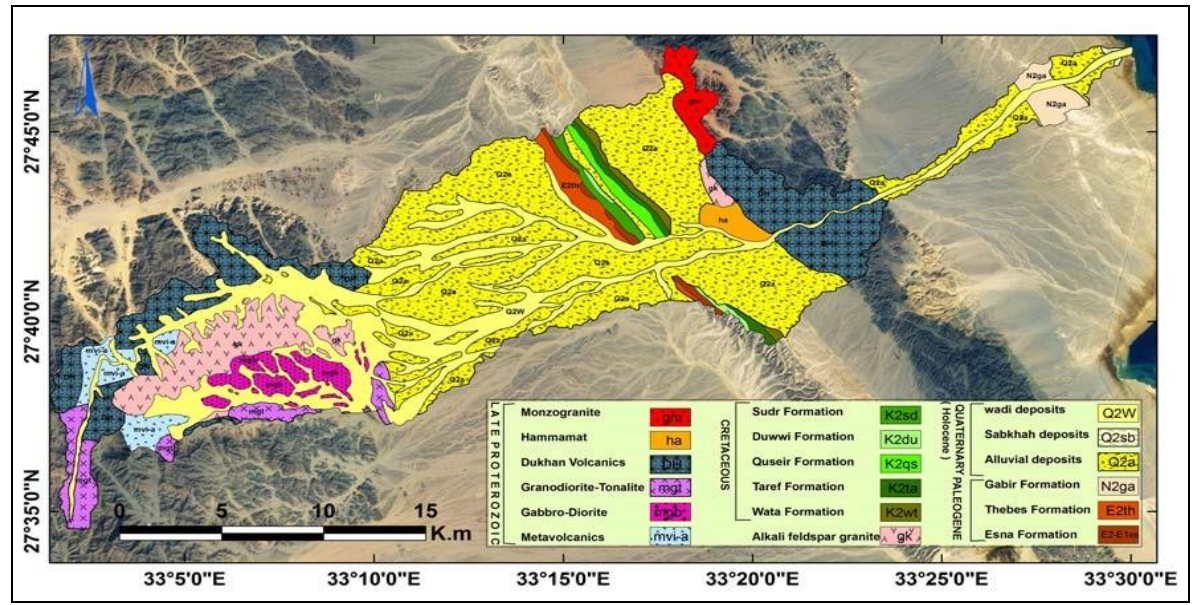

Geological map of Hurghada (Al Ghardaqh), Egypt, 2005, scale 1: 250000

Figure 2. Geological map of the study area.

\section{Data and Methods}

- Drainage network of Wadi Abu Had was extracted from aerial photographs and topographic maps of scale 1:50000 using digitizing capabilities in Arc GIS package, and make georeference.

- The current DEMs set for Wadi Abu Had area have been generated from digitized topographic maps of scale 1:50000, 1:25000, and the Shuttle Radar Topography Mission (SRTM) 3 arc second (90 m) data downloaded from ftp://edcftp.cr.usgs.gov/pub.

- Contours and drainage networks were digitized, and the top grid command in Arc GIS was used to create DEM with horizontal resolutions $(30 \mathrm{~m})$ (Fig. 3). The SRTM 3arc second DEM horizontal resolution is $90 \mathrm{~m}$ (Fig. 4). 


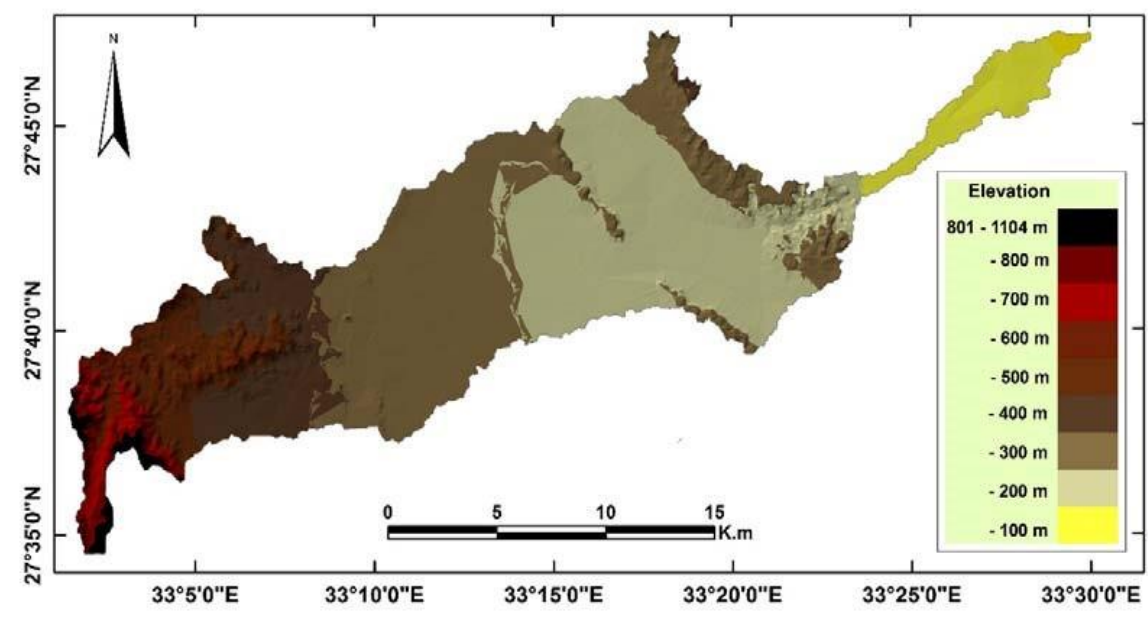

Figure 3. The DEM $30 \mathrm{~m}$ resolution.

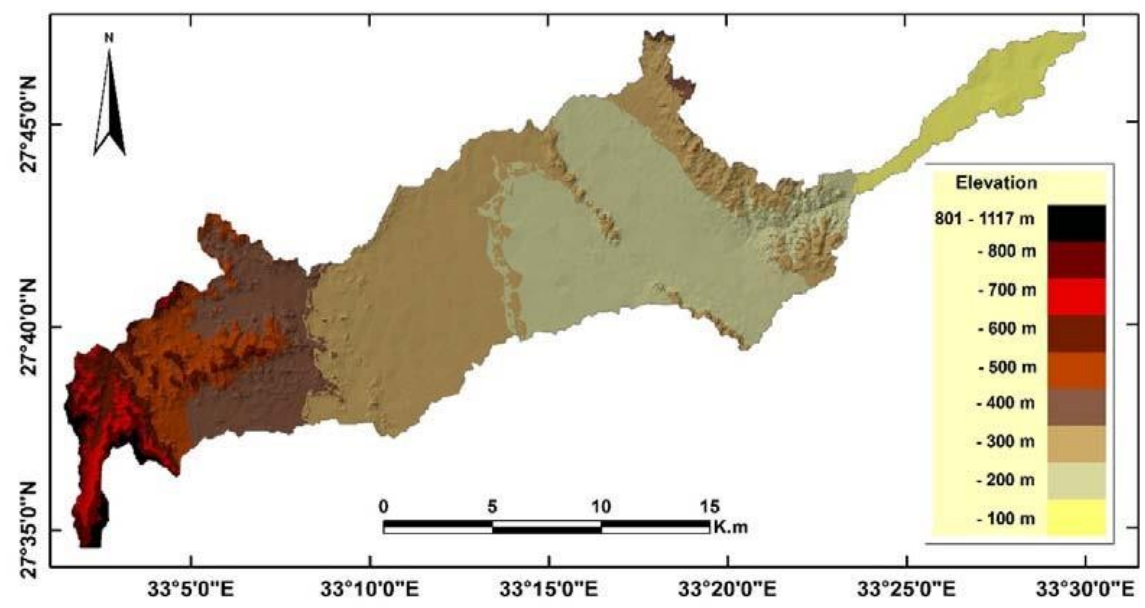

Figure 4. The STRM $90 \mathrm{~m}$ resolution.

The standard procedures within Arc GIS V.10 (Arc Tools, Hydrology) software were followed, for delineating drainage networks from the DEM and STRM. The extraction process consists of different steps of digital elevation modeling preprocessing; the Spatial Analyst extension and the Hydrology are used. 


\section{Preprocessing}

At first, the change format form DEM or STRM to ESRI's grid format should be used.

The following steps consist of the processing of DEM and STRM using the hydrology tools.

- Correction (fill): This method allows the user to do a low altitude cell stream and also provides the option to reduce gradually the neighboring cells along the stream. This method creates a normal transition from the bank for more than a centrist in the DEM to make the water stream interference. Thus, it was forced to flow in a moment extract network and will appear in the best adequacy with the reality of the terrain. Then, fill depressions and drilling by increasing the height of the hole to the level of cells surrounding terrain in order to identify trends of flow. These depressions are due to several mistakes made in a private building DEM interpolation. This effect can prevent the flow of water and can distort the hydrographic network.

- Flow direction: the direction of flow is determined using an algorithm D8. This one takes into account the eight neighboring cells from the point of view and calculates the difference between the maximum cell central and its eight neighbors. Accordingly, it will determine the direction of the flow of each cell according to the direction of the slope of the strongest identified.

- Flow accumulation: with the matrix used to determine the direction of flow, it is possible to calculate the flow accumulations. Upstream cells drain to a given cell. Drainage area at a given cell is computed by multiplying the flow accumulation value by the cell area.

- Definition Stream and feature: to determine where the water flow is going, this method uses a certain threshold. The cells with high flow accumulation, greater than predetermined threshold value, which is part of the power network.

- Water shed: to determine the basin area, the perimeter of basin and identifying water dividing belt between the Wadi under study and other. 
- Stream order: for the classification of streams within the drainage network. The Strahler method of stream orders based on a hierarchic ranking of streams has been used (Strahler, 1964).

\section{Drainage Network Output}

By applying the threshold of 20 cells to the flow accumulation grid, streams can be delineated. the threshold value is referred to as a threshold area, and represents the minimum upstream area required to form a channel segment in which water starts to flow as channel runoff (Rieger, 1993). The stream network usually displays interrelated stream linear features and begins these features where the threshold value is exceeded.

We can get different types of network patterns, lengths and density as a result of different contributing threshold area, superimposed on different topography.

A high threshold area value will create a drainage network with few streams, and the lower the threshold area, the higher the drainage density. For the sake of simplicity, an optimum threshold value can be determined by trial and error to obtain the best similarity between the DEM created drainage network and one traced from topographic maps (Band, 1986; Tarboton, et al., 1992; Wise, 2000). The up-slope contributing area threshold of $0.05 \mathrm{~km}^{2}$ yielded the best fit between the automatically extracted drainage networks from the different DEM sets, and the reference drainage network derived from the topographic maps (El Bastawesy, 2007).

\section{Discussion and Results}

There are differences between automated and source drainage networks; as result of the regular grid structure and limitations in the processing algorithms of DEM and STRM.

The delineation of source drainage networks on topographic maps is also fraught with uncertainties, especially for ephemeral streams. 
Moreover, intensity of the automatically extracted drainage systems automation is a function of contributing to the threshold of the area, such that the numbers low, threshold establishment of networks of exchange dense threshold is through trial and error in relation to a reference source. Overlay visual simple may not be a definitive method for determining the threshold representative, especially in the large catchments. Other features (attributes) must be compared to such as the length, order and counting. Flow length derived from a set of DEM $20 \mathrm{~m}$ or STRM $90 \mathrm{~m}$ resolution, showed that drainage lengths and numbers change slightly with resolution when the up-slope contributing area is fixed (Table 1).

\section{Drainage Network}

- In the current study, ranking of streams has been carried out based on the method proposed by Strahler (1964). The order wise streams statistics in (Table 1). It is also noticed that there is a decrease in stream frequency as the stream order increases in all methods.

- Studying the number of stream each extracted networking, it is found that there are clear differences between traditional and modern methods, especially at the first order; saluting the total number of the first order reached 3949 in topographic maps and 6796 of the aerial photographs, while amounted about 7968, 8423 in DEM and STRM, with high standard deviation reached. The total number of stream segments in all methods decrease with stream order. This is referred to as Horton's law of stream numbers (Fig. 5). Increase the numbers of the first order had reflected on their length in all methods.

- The sixth order represented the upper order of the drainage network derived from aerial photos and topographic maps, while the drainage network derived from the DEM or STRM reached the seven order; Perhaps this is due to the increasing numbers of first order extracted by automatic method, where the extracted reaches whatever length Unlike traditional methods that rely accuracy on personal experience. 


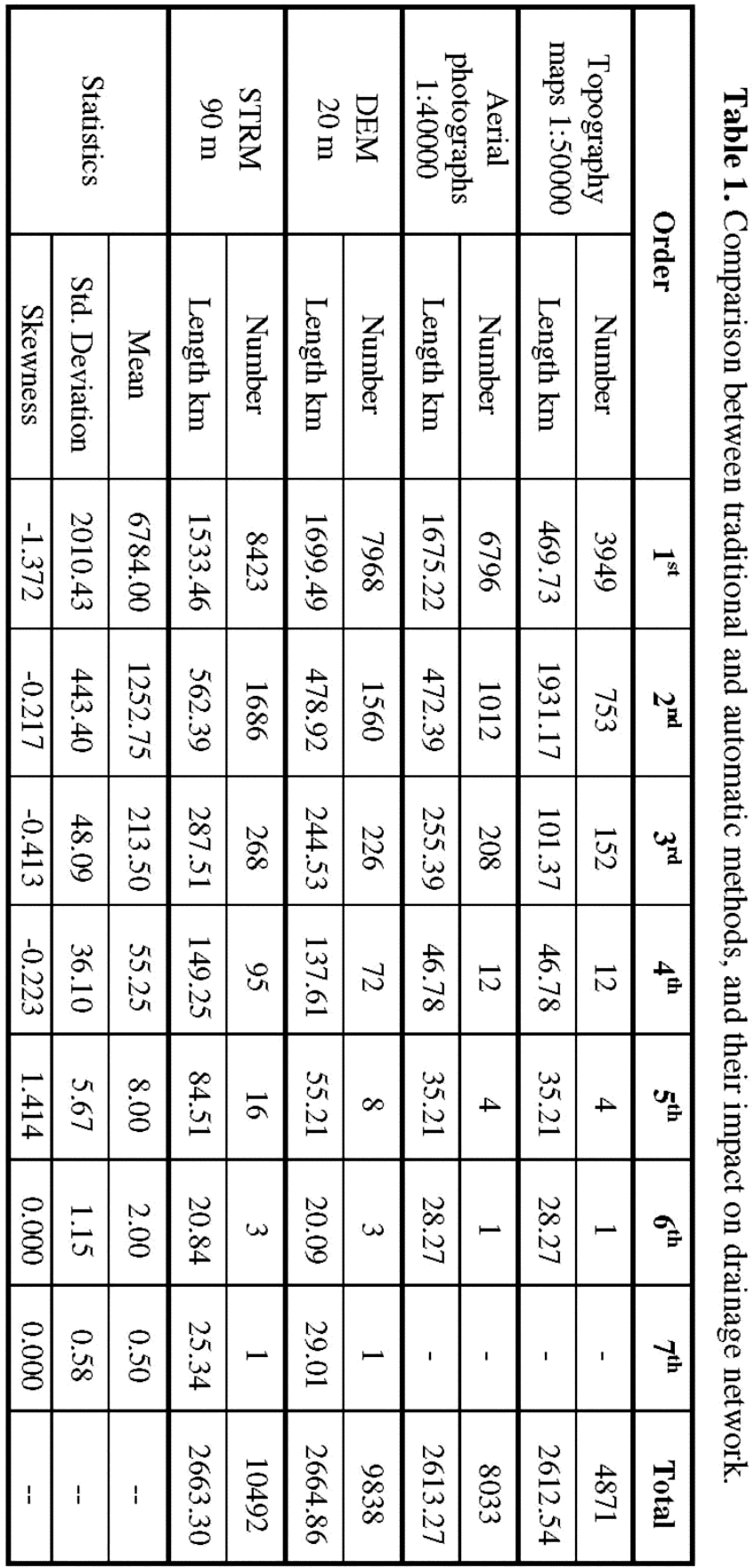

$-10-$ 
- The numbers of tributaries are Equal in the orders of sixth, fifth and fourth extracted by conventional methods, while equal numbers in the seventh order and sixth, formed orders from seventh to third less value of standard deviation for all the methods.

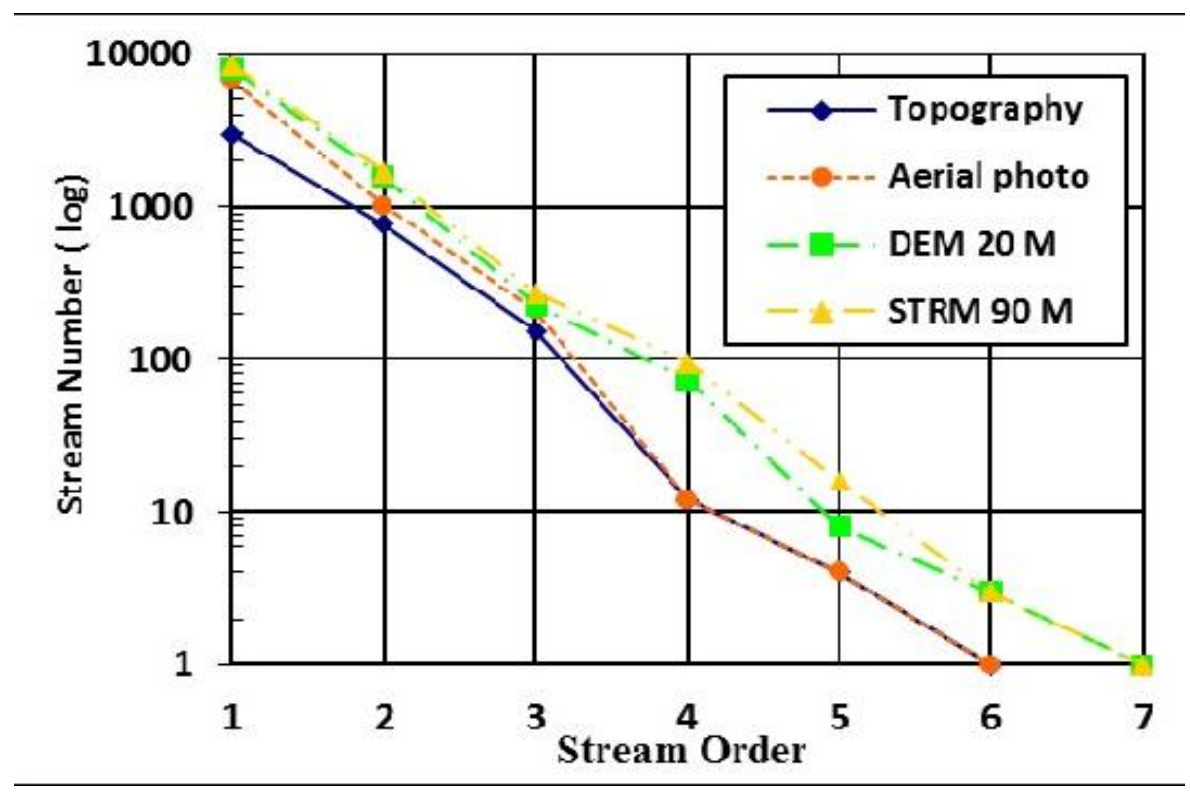

Figure 5. Influence of traditional and automatic methods on drainage networks numbering and orders.

The length of all streams has been computed based on the law proposed by Horton (1945). Generally, the total length of stream segments is maximum in first order streams and decreases as the stream order increases.

The result of mean stream length of (Aerial photo, DEM $20 \mathrm{~m}$, STRM $90 \mathrm{~m}$ ) methods, according to the Horton's law of stream lengths, But we have an exception in the third and fourth order in the network extracted from the topography maps, where the mean lengths of the third $0.67 \mathrm{~km}$ and fourth order $3.90 \mathrm{~km}$ (Table 2). 
Table 2. The mean lengths orders of basin Wadi Abu Had.

\begin{tabular}{|l|c|c|c|c|c|c|c|c|}
\hline \multicolumn{1}{|c|}{ The order } & $\mathbf{1}^{\text {st }}$ & $\mathbf{2}^{\text {nd }}$ & $\mathbf{3}^{\text {rd }}$ & $\mathbf{4}^{\text {th }}$ & $\mathbf{5}^{\text {th }}$ & $\mathbf{6}^{\text {th }}$ & $\mathbf{7}^{\text {th }}$ & Average \\
\hline $\begin{array}{l}\text { Topography } \\
\text { maps (km) }\end{array}$ & 0.12 & 2.56 & 0.67 & 3.90 & 8.80 & 28.27 & 0.00 & 0.54 \\
\hline $\begin{array}{l}\text { Aerial } \\
\text { photographs (km) }\end{array}$ & 0.25 & 0.47 & 1.23 & 3.90 & 8.80 & 28.27 & 0.00 & 0.33 \\
\hline $\begin{array}{l}\text { DEM 20 m } \\
\text { (km) }\end{array}$ & 0.21 & 0.31 & 1.08 & 1.91 & 6.90 & 6.70 & 29.01 & 0.27 \\
\hline $\begin{array}{l}\text { STRM 90 m } \\
\text { (km) }\end{array}$ & 0.18 & 0.33 & 1.07 & 1.57 & 5.28 & 6.95 & 25.34 & 0.25 \\
\hline
\end{tabular}

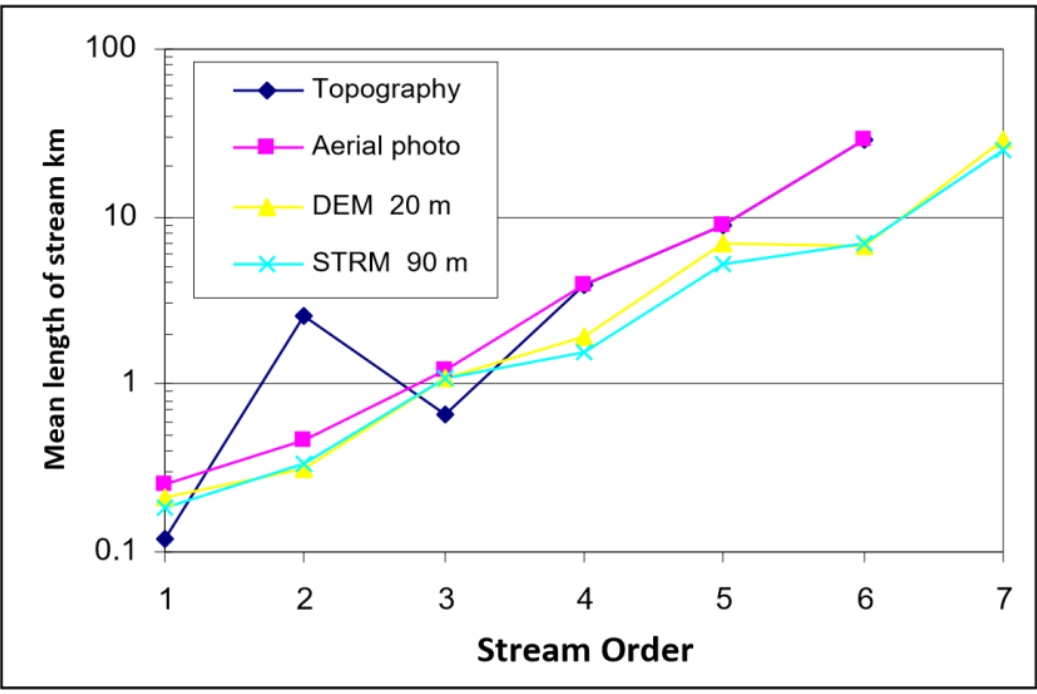

Figure 6. Relationship between mean length of stream and orders.

\section{Basin Geometry}

Some morphometric characteristics of the basin have been studied as follows:

\section{Basin Area:}

The area of the watershed is another important parameter like the length of the stream drainage (Schumm, 1956) that established an interesting relation between the total watershed areas and the total stream lengths, which are supported by the contributing areas. It created an 
interesting relationship between total water catchment areas and the total length of the stream, supported by the contributing areas. The areas were calculated for different methods to Wadi Abu Had using ArcGIS-10, (Table 3). The area of the basin extracted from the topographic maps highest value of $335.94 \mathrm{~km}^{2}$, while the area extracted from DEM the less valuable $310.95 \mathrm{~km}^{2}$ with a standard deviation of 10.88 .

\section{Basin Perimeter:}

Basin perimeter is the outer limits of the watershed that enclosed its area. It measured along the divide between the watersheds, and can be used as an indicator of watershed size and shape. Perimeter is extracted from the STRM overall average for all methods, and formed the basin perimeter extracted from aerial photographs and DEM lowest values, while the highest value in the topographic maps. There are minor discrepancies between all methods, Where values ranged between (171.72-158.90) with standard deviation 5.99.

\section{Length of the Basin:}

Basin length can be defined in several ways. Schumm (1956) defined the basin length as the longest dimension of the basin parallel to the principal drainage line. (Gregory and Walling 1973), definition of the length of the longest basin and in the basin, which is the end of being the mouth (Gardiner 1975), defined the basin length as the length of the line from a basin mouth to a point on the perimeter equidistant from the basin mouth in either direction around the perimeter. The author has determined length of the basin Abu Had in accordance with the definition of (Gardiner 1975) that is (48.95-50.98 $\mathrm{km}$ ) for all methods (Table 3).

\section{Elongation Ratio:}

According to Schumm (1965), elongation ratio is defined as the ratio of diameter of a circle of the same area as the basin to the maximum basin length. Strahler stated that this ratio runs between 0.6 and 1.0 over a wide variety of climatic and geologic types. The elongation ration of basin Abu Had ranges between (0.40-0.41), which reveals that the watershed is relatively elongated (Table 3 ). 


\begin{tabular}{|c|c|c|c|c|c|c|c|}
\hline 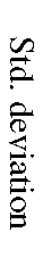 & $\begin{array}{l}3 \\
\stackrel{8}{8}\end{array}$ & 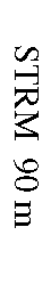 & 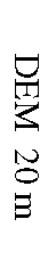 & 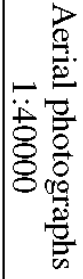 & 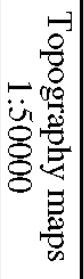 & $\begin{array}{l}\vec{\pi} \\
\stackrel{0}{0} \\
\stackrel{0}{0} \\
0 \\
0 \\
0\end{array}$ & \\
\hline$\dot{\infty}_{\infty}$ & 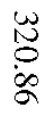 & $\frac{\omega}{\stackrel{N}{N}}$ & 崩 & $\begin{array}{l}\omega \\
\vec{u} \\
\dot{u}\end{array}$ & $\begin{array}{l}\omega \\
w \\
u \\
\vdots \\
+\end{array}$ & \multirow{2}{*}{ 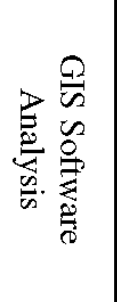 } & $\widehat{K}_{N} \underset{0}{0}$ \\
\hline ir & $\begin{array}{l}\vec{a} \\
\omega \\
\infty\end{array}$ & $\begin{array}{l}\overrightarrow{\hat{a}} \\
\mathrm{~N}\end{array}$ & $\begin{array}{l}\vec{y} \\
\dot{0} \\
\dot{0}\end{array}$ & $\begin{array}{l}\overrightarrow{u_{1}} \\
\dot{0} \\
\dot{0}\end{array}$ & $\underbrace{Ð}_{N}$ & & 졸 \\
\hline $\begin{array}{l}\infty \\
\infty \\
+\infty\end{array}$ & $\begin{array}{l}6 \\
6 \\
9\end{array}$ & $\begin{array}{l}\infty \\
\dot{\infty} \\
u\end{array}$ & $\begin{array}{l}B \\
\infty \\
w\end{array}$ & $\stackrel{0}{0}$ & $\begin{array}{l}\text { Un } \\
\dot{\infty}\end{array}$ & vo & 距 \\
\hline$\stackrel{8}{9}$ & $\dot{v}$ & $i_{0}^{v}$ & $i_{0}^{v}$ & $\dot{v}$ & iv & 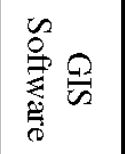 & হ \\
\hline 9 & $\stackrel{P}{ \pm}$ & $\stackrel{P}{ \pm}$ & $\stackrel{8}{8}$ & $\begin{array}{l}8 \\
8\end{array}$ & $\stackrel{P}{ \pm}$ & v & 四 \\
\hline$\stackrel{\rho}{9}$ & $\stackrel{\rho}{u_{r}}$ & $\stackrel{\rho}{u}$ & $\stackrel{\rho}{u}$ & $\stackrel{0}{a}$ & $\stackrel{P}{+}$ & 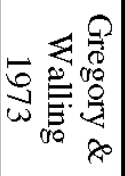 & 象 \\
\hline $\begin{array}{l}8 \\
8\end{array}$ & $\stackrel{\infty}{\infty}$ & $\stackrel{\oplus}{\omega}$ & $\stackrel{0}{U}$ & $\stackrel{0}{N}$ & $i$ & 胥 & 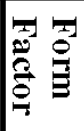 \\
\hline I & i & $\Xi$ & 8 & $\begin{array}{l}\vec{\delta} \\
\dot{u}\end{array}$ & $\begin{array}{l}\dot{\phi} \\
u \\
u\end{array}$ & 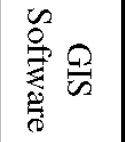 & 离 \\
\hline
\end{tabular}




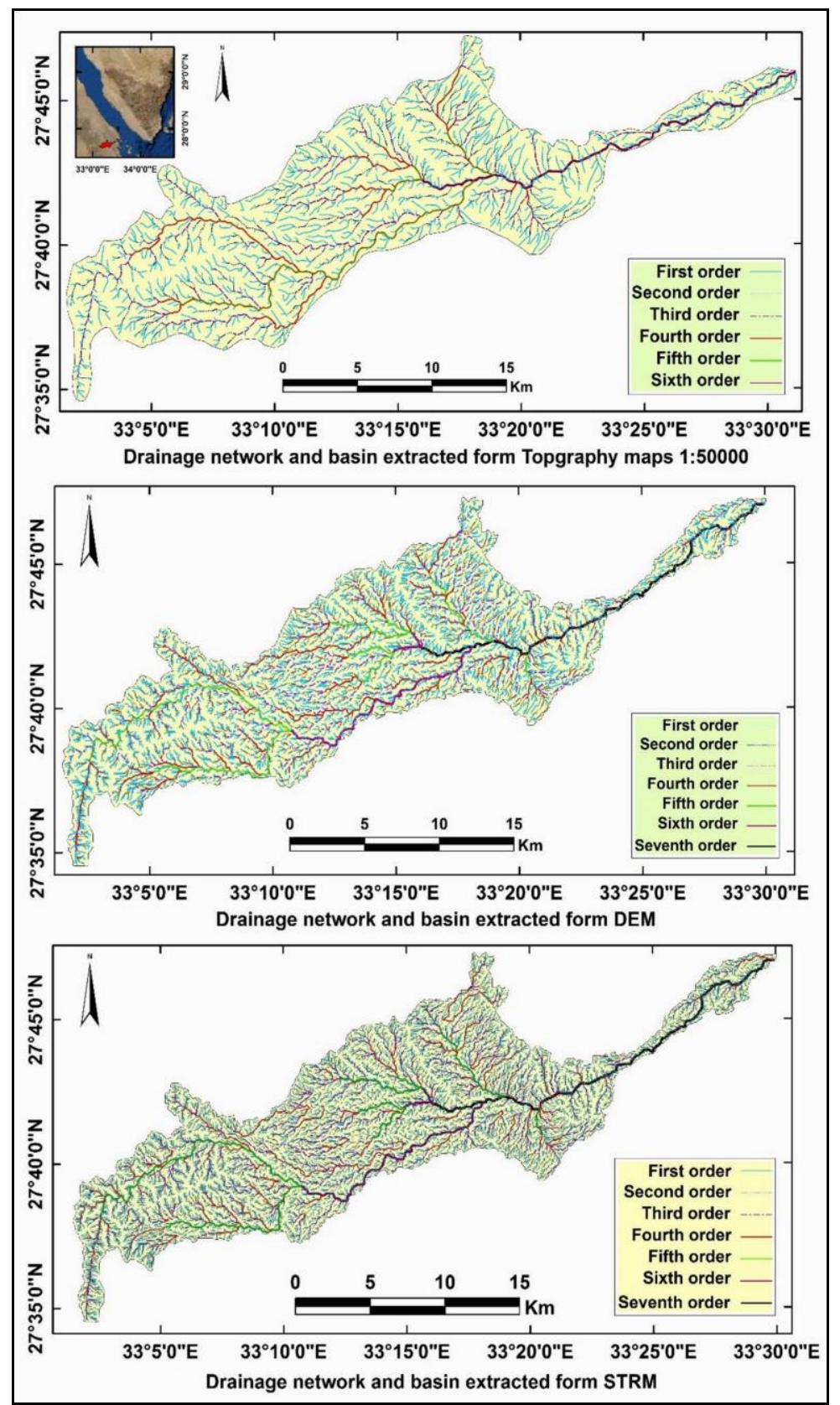

Figure 7. Comparison between traditional and automatic methods circularity. 


\section{Ratio:}

Circularity ratio is defined as the ratio of watershed area to the area of a circle having the same perimeter as the watershed and it is pretentious by the lithological character of the watershed. Miller (1953) has described the basin of the circularity ratios range 0.4 to 0.5 , which indicates strongly elongated and highly permeable homogenous geologic materials. The circularity ratio value (0.14-0.16) of the watershed corroborates with the Miller's range, which indicates that the watershed is elongated in shape (Table 3).

\section{Form Factor:}

According to Horton (1932), the form factor can be defined as a percentage of the basin area to square the length of the basin. The value of the form factor will always to be less than 0.754 (completely basin circular). Will value smaller form factor, more elongated be a basin? Basins with high form factors have high peak flows of a shorter duration, while basin elongated with a low form factor ranging from (0.125-0.135) suggesting to them that it is elongated in shape and the flow over a longer period (Table 3).

\section{Relief Ratio:}

Difference in the elevation between the highest point of a watershed and the lowest point on the basin floor (outlet) is known as the total relief of the basin. all methods not exceed 23 meters differences. However, there are minor discrepancies between the different methods of the basin area, perimeter, length of the basin, form factor and relief ratio.

\section{Conclusion}

The Abu Had watershed as identified and automatically delineated, has been extracted hydrographical network, and estimated some physical characteristics and morphometric parameters. The gain was a time of great importance since the manual extraction of long length can be submits mistakes.

Accuracy of the results depends on the resolution and quality of the DEM used and predefined threshold during the processing of the 
data. However, SRTM data can be considered with a resolution of 90 $\mathrm{m}$ can also be relied upon to conduct hydrological studies large watersheds.

Results of the physical elements, in particular the area of the basin and the hydrographical network, which are determined in this study, can be considered satisfactory.

All these digital data are proved useful for hydrological modeling, and offered us the better possibility to exploit the geographical information stored in the GIS.

\section{References}

1. Abdelkader, M., (2010) The contribution of the digital elevation models and geographic information systems in a watershed hydrologic research Appl Geomat, springer, vol. 2, pp.33-42

2. Babita P., Sailesh S., and Pal, D., (2012) Morphometric and hydrological analysis and mapping for

3. Watut watershed using remote sensing and GIS techniques, Int. J. of Advances in Engineering and Technology, vol. 2, Issue 1, pp. 357-368.

4. Band, L. E., (1986) Topographic partition of watershed with digital elevation models. Water Resources

5. Research, 22 (I), pp. 15-24. doi:10.1029/WR022i001p00015

6. Bradley, TH., Maidment, DR., (1999) Geospatial data in water availability modeling. Center for

7. Research Water Resources. Bureau of Engineering Research. The University of Texas at Austin J.J. Pickle Research Campus. Austin, TX 78712-4497, p 276.

8. Burrough, P. A. and McDonnell, R. A., (1998) Principles of geographic information systems, $2^{\text {nd }}$ edition. Oxford University Press, Oxford, 346P.

9. Chorowica, J., Ichoku, C., Riazanoff, S., Kim, Y., and Cervelle, B., (1992) A combined algorithm for automated drainage network extraction. Water Resources Research, 28 (5), pp. 1293-1032.

10. Chorley, R. J., (1969) The drainage basin as the fundamental geomorphic unit, in Water, earth, and man: a synthesis of hydrology, geomorphology and socio-economic geography, R. J. Chorley (Ed.), London: Methuen, pp.77-99.

11. El bastawesy, M., (2007) Influence of DEM Source and resolution on the hydrographical simulation of wadi keed catchment, Sinai, Egypt, Egypt J., Remote Sensing and Space Sci., vol. 10, pp. 53 - 62. 
12. Farr, TG, Kobrick, M., (2000) Shuttle radar topography mission produces a wealth of data. Am

13. Geophys Union Eos 81, pp.583-585.

14. Gamache, M., (2005) Free and low cost datasets for international mountain cartography. Alpine

15. Mapping Guild. Consulted online in January 2006 on http://www.terrainmap.com/downloads/Gamache_final_web.pdf

16. Garbrecht, J., and Martz, T., (1994) Grid size dependency of parameters extracted from digital elevation models. Computers and Geosciences, 20, 85-87.

17. Gardiner, V., (1975) Drainage basin morphology, British Geomorph. Research Group, Technical,

18. Bull. No.14, pp. 1-48.

19. Gregory, K.J., and Walling, D.E., (1973) Drainage basin form processes, A Geomorphological

20. Approach, London.

21. Horton, R. E., (1932) Drainage basin characteristics. Trans. Am. Geophys. Unions. 13, pp. 350-361.

22. Horton, R. E., (1945) Erosional development of streams and their drainage basins: Hydrophysical approach to quantitative morphology, Geol. Soc. Am. Bull.56: 275-370.

23. Jenson, S. K., and Domingue, J. O., (1988) Extracting topographic structure from digital elevation data for geographical information system analysis. Photogrammetric Engineering and Remote Sensing, 54, pp.1593- 1600.

24. Lawrence E. B., (2012) Topographic Partition of Watersheds with Digital Elevation Models American Geophysical Union. Issue published online: 19 DEC 2012.

25. Mark, D. M., (1984) Automatic detection of drainage networks from digital elevation models. Cartographic, 21, 168-178.

26. Mendas, A., (2010) The contribution of the digital elevation models and geographic information systems in a watershed hydrologic research, springer.

27. Miller, V., (1953) A Quantitative geomorphic Study of Drainage Basin Characteristics in The Clinch Mountain area , Project 389- 42 , tech Rept. 3, Columbia University

28. Pidwirny, J., (2006) Fundamentals of physical geography, http://www.fundamentalsofphysical geography.net 
29. Rieger, W., (1993) Hydrological terrain features derived from a pyramid raster structure. In Kovar. K, and Natchtnebel, H.P., (Eds.), Application of Geographical Information Systems in Hydrology and Water Resources Management, IAHS publication 211, Wallington, Oxford.

30. Schumm, S.A. ( 1956 ) Evolution of Drainage Systems and Slopes in badland at Perth Amboy New

31. Jersey, Bull. Amer. Geol. Soc., Paper No. 67, P.P.597-646

32. Strahler, A.N., (1964) Quantitative geomorphology of drainage basins and channel networks, section

33. 4-11, In: Handbook of Applied Hydrology, edited by V.T. Chow. McGraw-Hill, pp. 4-39.

34. Tarboton, D. G. and Ames, D. P., (2001) Advances in the mapping of flow networks from digital elevation data. The World Water and Environmental Resources Congress, Orlando, Florida.

35. Tribe, A., (1991) Automated recognition of valley heads from digital elevation models. Earth Surface Processes and Landforms, 16, 33-49.

36. Tamang, D.K., Dhakal, D., Shrestha, D.G., and Sharma, N.P., (2012) Morphometric analysis and prioritization of mini watersheds in Rongli watershed, Sikkim (India) using remote sensing and GIS techniques, Int. J. Fundamental Applied Sci. Vol. 1, No. 3 (2012): 61-66 http://bma.org.in/ijfas.aspx

37. Wise, S.M., (2000) Assessing the quality for hydrological applications of digital elevation models derived from contours. Hydrological Processes, 14, 1909-1929.

38. Wolock, D.M. and Price, C.V., (1994) Effects of digital elevation map scale and data resolution on a topographically based watershed model. Water Resources Research, 30, 3041-3052.

39. Zhang, W., and Montgomery, D.R., (1994) Digital elevation model grid size, landscape representation, and hydrological simulations. Water Resources Research, 30, 1019-1028. 